\title{
Can European Union (EU) Social NGOs Co-operate to Promote EU Social Policy?
}

\author{
ROBERT GEYER*
}

\begin{abstract}
This article examines why, despite similar general interests, institutional positions and political constraints, EU social NGOs find it so difficult to develop co-operative strategies except on the most fundamental issues. To demonstrate these difficulties the article considers the general reasons for and against co-operation between social NGOs and then examines the difficulties and advantages of collective EU social NGO action during the 1998 NGO funding crisis, Red Card protest and civil dialogue. The article argues that there is a fundamental desire for, and are benefits from, close co-operation between the EU social NGOs. However, due to the complex 'context structure' within which NGOs must operate, this co-operative impetus is constantly undermined. In conclusion, the article argues that social NGOs will remain weak and insignificant actors until the Commission/Parliament and/or the social NGOs can organise the complex context structure and allow co-operative strategies to emerge.
\end{abstract}

The fate of the European social model has been a central question of the 1980s and 1990s. Debates have raged over its definition, content and ability to defend itself against the pressures of economic globalisation and European integration (Hay, 1998; Hay and Marsh, 2000). A central aspect of this debate has been the development and potential role of EU social policy. An early assumption of defenders of the European social model was that a stronger EU social policy could act as a bulwark against international and European deregulatory and market-oriented forces (Martin, 1989). Built into this assumption was the hope that EU social policy could and should be promoted by a strong and extensive array of European level social non-governmental organisations (NGOs). Often labelled the 'civil dialogue', these social NGOs were supposed to form the political and institutional backbone of a social policy network which would help to maintain the 'human face' of the EU and by implication defend the fundamental European social model.

*Lecturer, School of Politics and Communications, University of Liverpool, Liverpool L69 7ZT. 
Despite the high hopes generated by the creation of the EU's Social Charter and Social Dimension in the early 1990s, EU social policy has failed to fulfil these hopes. Likewise, EU social NGOs have generally remained small, poor and weak organisations exercising only a limited degree of influence over the EU policy process and struggling to co-operate with each other on fundamental social issues and political strategies. Why have EU social policy and the EU social NGOs failed to develop?

The fate of EU social policy is a major issue and has been addressed in a number of larger works (Beck, 1998; Cram, 1993 and 1997; Falkner, 1998; Geyer, 2000; Gold, 1993; Hantrais, 2000; Leibfried and Pierson, 1995; Majone, 1993 and 1996; Springer, 1994; Sykes and Alcock, 1998). However, the plight of the social NGOs remains a new and unexplored area. This article will argue that, even if EU social policy had been more successful, EU social NGOs would have been unlikely to develop beyond their present position due to underlying blockages to their co-operative capabilities. Basically, despite similar general interests, institutional positions and political constraints, EU social NGOs are caught within a very complex and multi-level 'political opportunity structure' or 'context structure'(Marks, 1993; Marks and McAdam, 1996; Marks et al., 1996) which mitigates against co-operative strategies except on the most fundamental issues. To explore the nature of this complex and multi-level context, this article will examine the general reasons for and against co-operation between social NGOs. Then, it will explore the difficulties and advantages of collective EU social NGO action through a review of the 1998 NGO funding crisis, Red Card protest and civil dialogue.

This article will conclude by arguing that, due to the weakness of EU social policy and complex context structure, social NGOs remain very weak at the EU level. Further, the Commission and Parliament (the strongest institutional supporters of social policy development) have been unwilling/unable to significantly increase support and funding for social NGOs, or alter the complex context structure. If the social NGOs are going to progress, the EU institutions have to simplify their complex context and organise them and/or the social NGOs have to organise themselves. Arguably both steps are difficult, but necessary, for the future of social Europe.

WHY EU SOCIAL NGOS SHOULD CO-OPERATE AND WHY THEY DON'T There is a growing literature on EU interest group activity (Cullen, 1999; Greenwood, 1997; Greenwood and Aspinwall, 1998; Mazey and Richardson, 1993; McLaughlin and Greenwood, 1995; Pedler and Van Schendelen, 1994; Taylor, 2000) and there are a number of obvious reasons 
why EU social NGOs should be able to co-operate extensively. First, they are all, relative to most other EU interest groups, young, poor and weak. Most have only existed since the early 1990s, have minimal financial resources (under $€ 500,000$ annual budget), a few staff (generally under 5 staff members) and little institutional and political clout within the EU institutions and with their national and sub-national member organisations. Second, they generally rely on similar financial resources. Nearly all of the 30 members of the Platform of European Social NGOs (Platform) are heavily funded (60-90 per cent of total funding) by the EU. Third, they have and maintain an extensive informal network. Due to the small size and number of the social NGOs, their close proximity to each other in the centre of Brussels and their constant interaction at various European social policy forums they have evolved a significant informal network as well. Social NGO actors are aware of each other and are often on first name basis. Moreover, individuals working for one NGO may often find employment with another Social NGO. Fourth, they have a common formal network. Supported by the EU, the social NGOs have structured consultations through the Platform, the bi-annual meetings of the European Social Policy Forum, institutionalised twice yearly meetings between the Platform, Parliament, Commission and European Trade Union Confederation (ETUC) and frequent policy specific meetings regarding particular Commission proposals. Fifth, relative to other EU interest groups, social NGOs are ideologically similar and coherent. Their broad interest in social issues, containing market forces and promoting welfarist/social issues makes them politically and ideologically compatible. Consequently, they can often agree on broad policies and principles. Sixth, they are all caught within a similar institutional position. They are small and weak actors relative to the supportive Commission and Parliament and sceptical Council. The have little, if any, control over their national member organisations. Furthermore, they interact within similar international, European and national demands and constraints. Thus, they are often faced with similar pressures, demands and strategies. This fundamentally similar context should lead to the development of co-operative strategies for dealing with similar problems and opportunities. Seventh and lastly, as argued by neo-functionalists (Haas, 1958; Rosamond, 2000), with the successful expansion of European integration and the common market strategy in the 1980s and 1990s one would expect this success to spill-over into the social arena. As EU social policy expanded and became increasingly embedded in the European policy process one would expect social NGOs to be increasingly integrated and co-opted into the policy process. This integration should lessen their 
fundamental national antagonisms, increase the benefits of co-operative action and, thus, promote the development of collaborative/co-operative relations with each other.

On the other hand, a general overview of the social NGOs also presents several reasons why co-operative strategies could be very difficult to develop and maintain. First, despite their similar weak position relative to other non-social EU NGOs, there is a distinct hierarchy between the social NGOs. The most obvious indicator is staff and financial resources. The largest and most impressively organised are the European Youth Forum (EYF) and European Women's Lobby (EWL). With staff numbers of 16-20 and 10-12, annual budgets of $€ 2$ million and $€ 1$ million and an impressive network of expert advisors to draw upon, the EYF and EWL are capable of performing a variety of lobbying and advocacy activities (providing expert policy and legal advice, composing proposals for the Commission and Parliament, responding to legislative developments and competing for EU project proposals). At the other extreme would be organisations like Eurolink Age and Save the Children. Despite representing major organisations within the member states, both receive minimal (under $€ 100,000$ ) or no funding from the EU and have one to two staff members. Consequently, staff time and energies are concentrated on a few policies or events. Policy initiatives are minimal and scare time is often used to create proposals for projects with uncertain funding. Obviously, co-operative strategies between these actors must take into account their relative capability imbalances. From their position of strength, the EYF and EWL have little reason to put time and effort (altering their proposals, pushing for joint issues, making time to deal with their concerns, etc.) into co-operating with Eurolink Age or Save the Children. At the same time, Eurolink Age and Save the Children may fear that co-operation with a larger organisation would merely overwhelm their own activities.

Second, though most EU social NGOs rely heavily on EU funding, there is a marked difference between the three main types of funding (A-budget line funding, B-budget line funding and project funding) which the EU provides. Of the three types, A-budget line funding is the most stable and secure. Basically, A-budget lines are for funding EU administrative activities, are generally seen as long term economic commitments of over five to six years and are relatively immune from budgetary challenges in the parliament. Only a few social NGOs are funded with A-budget lines. The key examples are the EWL and the EYF. B-budget line funding is linked to particular policy areas and proposals, is based on two to three year programmes and is fully reviewed at the end of each programme. Currently, most of the funding for social NGOs comes through B-budget lines. These 
budget lines are much more unstable, politically weaker and must be constantly defended and justified by the social NGOs. Lastly, project funding is utilised by most social NGOs as well. However, project funding is generally short term (under one to two years), takes a significant amount of resources to obtain (particularly following the creation of detailed EU application, implementation and evaluation procedures) and carries no guarantee of further funding once the project is complete. These different types of funding create distinctive pressures and needs for the social NGOs. Not only must they compete over how the budget is allocated, but over the type of budget line which will support their activities and individual EU projects.

Third, as discussed earlier, the social NGOs display clear elements of an extensive and intensive informal network. However, this informality can easily lead to 'in' and 'out' groups and divisive personal struggles. During my recent interviews with social NGOs most respondents agreed that informal relations were generally good between the social NGOs. Nevertheless, there were clear antagonisms between some of the groups, particularly between poorly funded B-budget line NGOs and better funded A-budget line NGOs. Difficulties such as these are not unusual between interest groups, or most types of organisations. It is merely important to point out that these divisions create difficulties for co-ordinating common strategies between the NGOs.

Fourth, by most accounts, the Platform has been a successful formal network of organising social NGOs and co-ordinating their responses to common social policy difficulties and strategies. However, a number of tensions were apparent during my interviews with Platform members. Some members were concerned that they were not being heard by the Platform. Others were afraid that the Commission and parliament would increasingly turn to the Platform for consultations rather than to their own organisations due to the Commission's and parliament's desire for one single point of social NGO input. Some even complained that the Platform might become a career platform for particularly ambitious NGO actors. Overall, the Platform was seen as dynamic and useful, particularly during the past two to three years. Nevertheless, tensions within the members towards the Platform remain.

Fifth, despite general ideological similarities regarding social policy and welfarist issues, the social NGOs often represent groups that can be strongly antagonistic to each other. Some examples are obvious. The International Gay and Lesbian Alliance sits rather uneasily with the family organisations. Furthermore, my interviews revealed a number of tensions between other groups, which on the surface should be close 
allies, such as the EYF and Save the Children. The key point is that despite some general ideological similarities, these organisations often represent antagonistic groups and are caught within a competitive situation for funding and institutional attention from the EU. It is not surprising that group tensions would emerge.

Sixth, despite general similarities, their institutional position and context can vary remarkably. For examples, on top of international, European and member state dynamics the EDF has to deal with complex divisions within its own membership over types of disabilities and their relative importance within the disability movement. The EYF is a strongly EU oriented organisation with a significant and secure budget that pays little attention to other international organisations or issues. Meanwhile, the European Public Health Alliance has a strong link to the World Health Organisation and other international health forums and is hampered in its EU activities by the fact that it is linked to the only section of the Employment and Social Affairs DG (formerly DG5) that is based in Luxembourg rather than Brussels. Another example is the European Migrants Forum which has a very diverse and divided membership and competes against other European migrant organisations for EU funding and attention. The key implication is that like the complex and multi-level EU, social NGOs inhabit an even more complex and diverse universe of demands and interests. Given this complexity, it is impressive that these groups are able to co-operate at all.

Seventh and lastly, I would argue that some degree of spill-over has occurred and that social integration has been pushed forward by economic integration. However, this spill-over has not been even or constant. As discussed in other works (Geyer, 2000; Hantrais, 2000; Leibfried and Pierson, 1995), EU social policy has developed in fits and starts and is very uneven. EU social policy is well established in gender, youth and some areas of labour policy; less developed in disability, public health and anti-poverty policy; and poorly established in anti-racism and elderly policy. These differing levels of policy development generate different tactics and interests for the NGOs. NGOs in entrenched policy areas may try to focus on legal channels and strategies to further their particular agendas. Meanwhile, NGOs in weaker areas may focus all of their energies on a new legislative initiative or treaty base. These differing conditions and strategies may easily generate tensions and divisions between the more and less successful social NGOs. Moreover, these differences are very unlikely to be dissipated in the near future.

Overall, this general review oversimplifies the issue of co-operative vs. conflictual dynamics between the social NGOs. Undoubtedly, a significant 
amount of co-operative behaviour is occurring between the groups. Nevertheless, this co-operation is not easy or automatic and has to overcome significant and complex clashes of interest and institutional positions. To explore more concretely the delicate nature of social NGOs' co-operative strategies the article will now turn to the cases of the 1998 funding crisis, Red Card protest and current campaign to promote the civil dialogue.

THE 1998 FUNDING CRISIS, RED CARD CAMPAIGN AND CIVIL

DIALOGUE

As most observers would admit, funding for EU social NGOs emerged in a random fashion. Some groups received funding in the 1980s and have Abudget lines (the EWL and EYF). Most groups were founded in the 1990s and funding was based on Declaration 23 of the Maastricht Treaty which stated that:

The Conference stresses the importance, in pursuing the objectives of Article117... of cooperation between the latter and charitable associations and foundations as institutions responsible for social welfare establishments and services

These groups receive a combination of B-budget line funding and project based funding. This ad hoc development was due to several factors. The fact that the EU was pushing into new social policy areas, which lacked a base in the treaties, made clear funding guidelines difficult. Also, the development of parliament's powers of budgetary oversight complicated the politics of funding for social policy NGOs. The Parliament has generally been a keen supporter of social policy. However, as the political complexion of parliament changes, so do its social policy positions. Lastly, although the Employment and Social Affairs DG (formerly DGV) has been a strong social NGO supporter it is also caught within budgetary struggles with different DGs and the Council. Consequently, funding for NGOs has been uneven, unstable and lacking an overall coherent strategy or justification.

This incoherence was starkly highlighted by the impact of Case 106 of the European Court of Justice (ECJ). In May 1998 nearly $€ 1$ billion of EU social policy funding was brought into question by the results of a decision from the ECJ on Case 106/96. The issue upon which this decision was based was located in the inter-institutional struggles between the EU Council and EU Commission. In 1994, the Council rejected the Commission's 1994 EU anti-poverty programme. The Commission and Parliament responded by attempting to continue funding some of its earlier anti-poverty programmes through their discretionary budgetary 
powers. In 1996, the British Conservative government (backed by Germany, Denmark and the Council) challenged the right of the Commission to allocate these funds without a 'legal base', such as a Decision from the Council. On 12 May 1998, the ECJ found in favour of Britain, arguing that the Commission had spent money to finance 'significant' actions which the Commission could only do if it had a legal base (i.e. a Council decision). Following the ECJ's ruling, on 10 June the Commission decided to launch a review of all budget lines (over 100) without a legal basis and to freeze all lines without a legal base during the review process. This result unleashed a wave of confusion in the EU institutions since it curtailed the right of the Commission to allocate nearly $€ 1$ billion of social funding, reasserted the power of the Council over the Commission, and antagonised the EU Parliament since many of its small projects were funded with discretionary Commission funds.

EU social NGOs were shocked and dismayed. Not only was their project funding under threat, but their own existence was threatened as well since many received a substantial proportion of their organisational income from the EU. In response, the social NGOs took three key steps: the mobilisation of social NGOs through the Platform, the publicising of the crisis through the Red Card campaign and the formation of an alliance with development NGOs and human rights NGOs.

In many ways, this was the crucial moment for the Platform. The Platform had only been established in the mid-1990s and was still struggling to find a clear role in its relationship to the social NGOs. As shown earlier, the distinctive positions and interests of the social NGOs makes it very difficult to find clear 'horizontal' issues which they could all agree upon. However, the funding crisis was just such an issue. The Platform quickly became the centrepoint for organising the response to the funding crisis, organising actions at member state and the European level. For example, it encouraged all member organisations to write letters to their MEPs, Council representatives and national governments protesting the crisis. Further, using the Social Policy Forum, a bi-annual meeting of over 2000 social NGOs which just happened to be occurring in late June 1998, the Platform organised a 'red card' protest. Taking its signal from the World Cup (going on in France at that time), the Platform distributed 'red cards' to all of the participants at the Social Policy Forum. Whenever an EU official was present the participants would show them the 'red card'.

To co-ordinate the 'red card' protest and meetings with EU officials, the Platform formed an alliance with the development and human rights NGOs. This alliance led to an impressive and unprecedented degree of 
publicity for the normally unknown social NGOs and the funding crisis. Co-ordinated by the Platform, this grouping had two main demands. They called for an immediate resumption of budgetary allocation for all of the NGO budget lines. The key point for all of the NGOs was that their various budgets were frozen. They could do nothing, continue existing operations, plan for future developments and/or pay staff (!), until the crisis was resolved. Furthermore, they demanded that the larger issue of the general status of NGOs and their relationship to the EU institutions be addressed. As a May 1998 Platform document argued before the funding crisis:

At present, there is no legal basis for consulting NGOs. Consultations are still initiated by the individual Commission Directorates General when they feel the need with no moves to draw everything together. The first essential step in this direction is for the Commission to compile a List of INGOs [International Non-Governmental Organisations] with which it would consult on a regular and systematic basis...The compilation of this List would also be an opportunity for regulating the relations between listed INGOs and the European Commission in a formal legal instrument, setting out the rights and duties of each. (Platform, May 1998)

Under pressure from this alliance the Commission and Parliament began to actively seek ways to keep the complicated array of programmes afloat while social NGOs struggled to make sure that their particular policy areas were saved. The immediate goal of the Platform was to release the funds already allocated in existing budget lines. Pressure continued until the Budget Council meeting on 17 July when over 75 per cent of budget lines were unblocked. Furthermore, the Council encouraged the Parliament and Commission to find appropriate bases for the still blocked lines, particularly re-framing and re-grouping them under Article 13 and/or 137 of the Amsterdam Treaty. The Council also clarified the definition of a 'pilot action' and a 'preparatory action' and set spending and time limits for both. Most importantly for the NGOs, the Council decided that preparatory actions connected to the Amsterdam Treaty could start before the ratification of the treaty and that a preparatory action could continue even if a programme from which it is proposed is still awaiting a legal basis. This was absolutely essential to maintain funding for the NGOs through 1998 and 1999. However, it left the budgetary position beyond 1999 uncertain.

Throughout 1999 and 2000, the Platform, social NGOs and their supporters in the Commission and Parliament worked tirelessly to create a more stable and secure position for the social NGOs. This work revolved around the institutionalisation of the civil dialogue. Before discussing their most recent activities it is necessary to take a brief look at the foundation of the idea of the civil dialogue. 
The idea of the civil dialogue has its roots in the political traditions of the Netherlands and Germany and had been discussed within the EU since the early-1990s (Kendall and Anheier, 1999; Platform, November 1999; Taylor, 2000). Declaration 23 of the Maastricht Treaty mentioned the importance of dialogue between the EU and 'charitable associations and foundations... responsible for social welfare establishments and services'. In 1996, the report from the Committee of Sages on the future of civil and social rights in Europe concluded that both a social dialogue (involving capital, labour and the EU) and a civil dialogue (involving the broader NGO community and the $\mathrm{EU})$ were necessary for the promotion of fundamental rights:

Non-governmental associations and organisations seem likely to play an increasing role in society, especially as regards the rights of the unemployed and the elderly. How they can be recognised as partners in this slow, self-transforming progress of society towards the recognition and implementation of new rights, especially those intended to prevent or end exclusion, is thus an important aspect of the fundamental rights question. (Committee of Sages, 1996, p. 55)

Furthermore, at the same time Employment and Social Affairs DG in the Commission and the Social Affairs Committee in the Parliament were working together to promote a more general Social Policy Forum, a biannual mass meeting of all NGOs linked to the social field. The first was held in 1996 and the second in 1998. Despite the significant participation of NGOs (over 2000 attended the second forum) and the success of the second forum at helping to raise the funding crisis issue, general NGO opinion of the forums was divided. Most NGOs found the forums useful, but did not see them as a replacement for full consultation with the EU institutions (Hughes, 1999, p. 3). Lastly, in 1996 the Commission and Parliament created and funded the Platform of European Social NGOs in order to strengthen the voice of and co-ordination between the social NGOs and consequently the civil dialogue.

The Employment and Social Affairs DG, Platform and, in particular, Employment and Social Affairs Committee in the Parliament (led by MEP Stephen Hughes until mid-1999 and currently chaired by the French MEP M. Rocard) continued to press for a more institutionalised form of civil dialogue. The Committee held a series of hearings on the civil dialogue in early 1998 with the social NGOs. The conclusions of these hearings were integrated into the Parliament's Ghilardotti Report on various aspects of the non-profit sector. The conclusion of the report called for, 'a serious, structured sectoral dialogue to be set in motion between the European institutions and the NGOs represented at European level' and saw the Platform as a model for other sectors of the civil dialogue (Hughes, 1999, p. 5). Following this, the Commission and the Parliament both established 
regular twice yearly meetings with the Platform. Despite these developments, the Commission did not include a call for the development of a civil dialogue in its 1998-2000 Social Action Programme.

In the aftermath of the funding crisis, the Platform has concentrated much of its resources on the creation of the civil dialogue. In June 1999 it published a document on social NGO funding which made four proposals for strengthening the civil dialogue:

1. European NGOs who comply to clearly laid out criteria of representativity, effectiveness, good governance and management and compliance with equal opportunities should be eligible to receive core funding, which should be on a multi-annual basis and include appropriate secretariat and management costs, as well as the costs of convening statutory meetings.

2. An equitable and efficient schedule for grant applications and payments needs to be put in place...

3. Projects and budgets should be agreed in principle between the Commission and the NGO at least four months before the start of the year.

4. The responsibility for the matters such as contracts, payments, calls for projects and problems over funding should be clearly defined both at the level of officials and at the political level. (Platform, June 1999, p. 2)

Later, in October 1999, after the Platform was made aware of a forthcoming Commission document on the civil dialogue, the Platform attempted to structure the early debate with a number of 'political recommendations'. In this document, the Platform re-emphasised the important role of the social NGOs and stressed the importance which Declaration 38 of the Amsterdam Treaty gave them:

The Conference recognises the important contribution made by voluntary service activities to developing social solidarity.

However, the Platform emphasised that there was a growing need to develop a 'more horizontal and coherent approach to the consultation of NGOs' which would be based on, 'an Article (in the Treaty of the European Union) to give a legal underpinning to the civil dialogue' (Platform, October 1999 , p. 2). Finally, in order to implement the dialogue, it should be made into a 'structured process, which includes the elaboration, monitoring and evaluation of EU policies'. Also, the Commission should, 'compile a list of accredited NGOs operating at the EU level with which it would consult' (Platform, October 1999, p. 2). 
Overall, the Platform was trying to play both a detailed and general strategy. At the detailed level, it was trying to solve a number of the annoying budgetary aspects of the social NGO - EU relationship including issues of timing for payments, criteria for EU funding eligibility and defining responsibilities. These were obvious small problems that were afflicting a number of social NGOs. However, this detailed strategy was linked to the larger one of institutionalising the civil dialogue in the EU treaty and forcing the EU to create a list or system for accrediting and supporting social NGOs. This combination of strategies was clearly necessary to satisfy the needs of the social NGOs who were directly affected by the funding crisis and the interests of those who were less affected. Moreover, the emphasis on getting the EU to create a list of accredited NGOs was particularly interesting in that the Platform clearly wanted to avoid being the group responsible for picking which NGOs were, and were not, acceptable. This would put it in a delicate political situation it did not desire, nor was capable of resolving.

Unfortunately for the Platform and social NGOs, the Commission and Council were reluctant to quickly alter the existing nature of the civil dialogue. In its most recent document on the civil dialogue, after listing the various benefits of the civil dialogue, the Commission resisted a number of the Platform's demands. In relation to the complaints about the overly bureaucratic proposal process, the Commission argued that:

Regarding funding, the NGOs must accept, for example, that there will always be a legitimate need for the Commission to impose certain conditions and controls to safeguard community funds. NGOs have a duty to demonstrate that they have the expertise, management systems and internal quality control systems appropriate to the work they are undertaking. (Commission, 2000, p. 9)

For the existing informal contacts between the NGOs and EU, 'the steering group sees the current informal co-operation as useful and wishes it to continue' (Commission, 2000, p. 11). However, the document did stress that, "The Commission therefore wishes to develop a framework of principles for creating a more structured dialogue with NGOs' (Commission, 2000, p. 12). The document went on to outline the possible lines of debate over how best to institutionalise the civil dialogue. Regarding a new legal basis for the civil dialogue, the document only mentioned it in passing and made no specific proposals. Regarding funding issues, the document noted that the division between A- and B-budget lines was incoherent and arbitrary and that the Commission intends to develop a new system. However, this was clearly linked to a variety of other issues and was not expected to be resolved until the 2001 budget. Lastly, the document rejected the demands for the Commission to accredit 
social NGOs arguing that the Commission had always, "wanted to maintain a dialogue which is as open as possible without having to enforce an accreditation system' (Commission, 2000, p. 14).

As of Summer 2000, the state of affairs for the funding crisis and civil dialogue is one of stasis and small-scale adjustments. The Parliament and Commission recognise that the system of funding for the social NGOs is ad hoc and confusing. However, the solution to these difficulties is wrapped around a number of larger administrative and political issues. For example, the elimination of the distinction between A- and B-budget lines will obviously have a fundamental impact on the administrative functioning of the entire EU. Moreover, not only is this an administrative problem but it has clear political implications as well. The social NGOs benefited from a supportive Parliament which was able and willing to establish multiple and ad hoc budget lines to support them. Rationalisation of these budget lines may not only threaten the social NGOs, but it may threaten the power of the Parliament in relation to the Council. Finally, in the Presidency conclusions at the March Lisbon Council, the Council concluded, under the section on 'promoting social inclusion' that it will,

pursue its reflection on the future direction of social policy... with a view to reaching agreement on a European Social Agenda at the Nice European Council in December, including the initiatives of the different partners involved.

The issue of the civil dialogue is alive, but it is clearly going to have to wait until December 2000 before the Council will take a view on it.

\section{CONCLUSIONS}

As is well known, the EU is a complex multilevel institution. At the centre of this complexity are the social NGOs, busily balancing member, national, European and international developments, interests and strategies. In this complex context structure, co-operative action is difficult to achieve even with a number of institutional similarities and formal and informal networks. As the funding crisis and its aftermath demonstrated, only the most basic of issues can result in significant and sustained co-operative action. The crisis not only provided a focus for collective action for social NGOs, but encouraged the revival of the languishing Platform and created opportunities for linkages to other environmental and development NGOs and labour organisations. Nevertheless, other, less fundamental issues, would be unlikely to generate this level of co-operative activity.

If the above is correct, then the solution to the collective weakness of the social NGOs would be to simplify or organise their complex context 
structure in order to create more common issues around which co-operative strategies could emerge. In the context of a complex and multilevel EU, this would not be an easy task. Nevertheless, there are two main groups of actors who could potentially do it: the EU institutions (particularly the Commission and Parliament) and the social NGOs. As seen above, the Commission and Parliament have been strong supporters of social NGOs, but have been unable or unwilling to increase and organise NGO funding or act as a gatekeeper/organiser for social NGOs. The funding issue is obviously linked to larger political battles within and between the Parliament, Commission and Council. Greater funding would clearly have an immediate impact on the NGOs. However, in the current context it is extremely difficult to imagine a constellation of political forces which would enable significantly greater funding. Moreover, the unwillingness of the Commission and/or Parliament to act as a gatekeeper seems to be based on a desire to maintain the pluralism of the social NGO community, to avoid direct responsibility for the funding situation of the social NGOs and to continue the complexity of the budgetary process in order to avoid the reassertion of Council control over budgetary procedures. Nevertheless, these blockages will have to be overcome by pro-social policy forces within the EU if a more powerful social NGO movement and social policy are to be created. The Commission and/or Parliament will have to accept a greater degree of responsibility for the social NGOs including: greater funding, more equal funding and acting as a gatekeeper of funded NGOs. This raises obvious problems of NGO independence in relation to the EU. However, in the current context, where NGOs are so weak, it may be a reasonable price to pay.

The other key actors are the social NGOs themselves. Driven by their weakness and their formal and informal networks, the social NGOs have already developed a degree of co-operative activities and co-ordinated policy action. However, their divergent interests and complex context structure constantly undercut these collective strategies on all but the most fundamental issues. One response to this weakness could be greater NGO organisation. Using the Platform as a base, the NGOs could agree to pool their limited resources to demand greater and consistent funding and key policy strategies for a recognised group of social NGOs. In essence, the Platform, or some similar organisation, would become the NGO gatekeeper, removing the administrative and political burden from the Parliament/Commission and strengthening the organised NGOs in the process.

This strategy is full of obvious risks and difficulties. How would one determine an 'acceptable' social NGO? How would funding be allocated? Would 
it lead to a more powerful social NGO voice? Would the organised social NGOs be co-opted by the EU and ignore their national and sub-national roots? There are no clear answers to these questions. Nevertheless, the risks may be worth taking. At present, the social NGOs have a great deal of freedom, but little influence. Sacrificing some of their independence for greater organisational coherence may be the only way for them to significantly promote EU social policy.

Lastly, it is likely that some combination of these two strategies may emerge, combining a stronger central social NGO organisation with greater regulation by or reliance on the Commission and Parliament. Predicting the exact structure is clearly beyond the limits of this article. Nevertheless, given the current complex context structure, social NGOs will have to be organised or organise themselves in order to become a major factor in the future of EU social policy.

NOTES

1 The Platform was created in mid-1996 to promote and co-ordinate the development of the social NGOs. It has a small staff (four to five members) and is primarily funded by the EU.

2 Recently, the general secretary of a leading social NGO moved on to a position in the Commission and was replaced by the head of another social NGO who was married to the head of another social NGO. This is not an attack on any of these individuals. It merely highlights the very close informal relationships between the social NGOs.

3 Both Employment and Social Affairs P. Flynn and A. Diamontopoulou have encouraged the social NGOs to comment on both general and specific social policy proposals. In March 2000, Commissioner Diamontopoulou has issued a general social policy proposal outline to the social NGOs in order to develop strategies and ideas and gauge the level of political support for certain initiatives.

4 In October 2000 Eurolink Age merged with two other organisations to form the European Older People's Platform. According to the Director of Eurolink Age, this was done to strengthen the influence of organisations for older people and to create a 'more European' organisation to enhance funding possibilities from the EU level.

5 A recent exception to this was the challenging for the EWL's A-budget line in the parliament by the Irish MEP Dana Rosemary Scallon, the former Eurovision song contest winner, who was rumoured to have opposed the funding of the EWL because of its stance on the right to abortion.

6 I performed twenty-one semi-structured interviews during 21-29 March 2000. These included twelve members of the Platform of European Social NGOs, actors within the Platform, Commission, Parliament, and ETUC. All of the interviewees were selected because of their close engagement with the EU social policy process. Of the Platform members, I interviewed disability, anti-poverty, youth, elderly, family, gender, child, anti-racism, and health organisation representatives. They were selected to provide a wide spread of social issues and to obtain a general balance between large (gender, youth, disability) and small (elderly, child and family) organisations. The interviews were open, but structured around three main areas: the impact of the funding crisis on the NGO and NGO community, the activities and usefulness of the Platform and the challenges to collective action within the NGO community. Interviews with Non-NGO actors were oriented towards obtaining information about the budget crisis, Red Card protest and civil dialogue, the position of the governmental actors towards the NGOs and Platform and their views regarding the future of EU social policy.

7 This incoherence may be in the interest of the Parliament since it is a demonstration of the Parliament's control over the budget process. If there were clear lines of control and spending 


\section{Robert Geyer}

guidelines, the Council would be in a better position to exert detailed control over the budget process.

8 Social NGOs appealed to the new Labour government in 1997 to withdraw the case. However, it chose not to do so.

9 The Commissioner for the budget, Mr. Liikanen, was accused of interpreting the ECJ's ruling in an unnecessarily strict manner by Commissioners Bonino and Flynn. However, a number of scandals had already rocked the Commission and it was not surprising that Liikanen was determined to pursue a hard line.

10 In a Platform document written after the 'Red Card' protest, the Platform admitted that: 'the Social Forum had been a heaven sent opportunity' (Platform, October 1998, p. 9).

11 Even the British newspapers, generally unwilling to notice any social policy activity at the EU level, carried various articles on the budget crisis and social NGOs' activities.

12 A pilot action is an exploratory expenditure which may or may not lead to a programme. It may not last over two years and cannot spend over $€ 16$ million in any year. A preparatory action is an action leading to the creation of a programme with a legal basis. It may last three years and not exceed $€ 75$ million in expenditure.

13 A fifth lesser proposal included a call to reform the Vademecum agreement on bank grants over $€ 100,000$.

\section{REFERENCES}

Beck, W. et al. (eds.) (1998) The Social Quality of Europe, The Policy Press, Bristol.

Commission of the European Union (2000), The Commission and Non-governmental Organisations: Building a Stronger Parnership, Commission, Brussels. (COM(2000)11.final. 18 January 2000).

Committee of Sages (1996), Report of the Committee of Sages: For a Europe of Civic and Social Rights, Commission, Brussels.

Cram, L. (1993), 'Calling the tune without paying the piper? Social policy regulation: the role of the commission in European union social policy', Policy and Politics, 21: 135-46.

Cram, L. (1997), Policy-making in the European Union: conceptual lenses and the integration process, Routledge, London.

Cullen, P. (1999), 'Pan-European NGOs: EU sponsored mobilization and activism for social rights', Manuscript.

Falkner, G. (1998), EU Social Policy in the 1990s, Routledge, London.

Geyer, R. (2000), Exploring European Social Policy, Polity Press, Oxford.

Gold, M. (ed.)(1993), The Social Dimension: employment policy in the European Community, Macmillan, London.

Greenwood, J. (1997), Representing Interests in the European Union, Macmillan, London.

Greenwood, J. and M. Aspinwall (eds.) (1998), Collective Action in the European Union, Routledge, London.

Hantrais, L. (2000), Social Policy in the European Union, 2nd edn, Macmillan, London.

Haas, E. (1958), The Uniting of Europe, Stanford University Press, Stanford.

Hay, C. (1998), 'Globalisation, welfare retrenchment and the logic of no alternative: why secondbest won't do', Journal of Social Policy, 27, 4.

Hay, C. and D. Marsh (eds.)(2000), Demystifying Globalisation, Macmillan, London.

Hughes, S. (1999), 'Working document on the development of the civil dialogue', European Parliament, 11 May (PE 230.210/fin).

Kendall J. and Anheier, H. (1999), 'The third sector and the European Union policy process: an initial evaluation', Journal of European Public Policy, 6, 2.

Leibfried, S. and Pierson, P. (eds.) (1995), European Social Policy: between fragmentation and integration, Brookings Institute, Washington, DC.

McLaughlin, A. and Greenwood, J. (1995), 'The management of interest representation in the European Union', Journal of Common Market Studies, 33:1, 143-56.

Majone, G. (1993), 'The European Community: between social policy and social regulation', Journal of Common Market Studies, 31: 2, 153-69. 
Majone, G. (1996), Regulating Europe, Routledge, London.

Marks, G. (1993), 'Structural policy and multi-level governance in the European Community', in A. Cafruny and G. Rosenthal (eds.), The State of the European Community (vol. II), Lynne Rienner, New York.

Marks, G., F. Scharpf, P. Schmitter, and W. Streeck (1996), Governance in the European Union, Sage, London.

Marks, G. and D. McAdam (1996), 'Social movements and the changing structure of political opportunity in the European Union', West European Politics, 9, 2.

Martin, D. (1989), 'A left agenda for Europe', Contemporary European Affairs, 1, 1.

Mazey, S and J. Richarson (eds.) (1993), Lobbying in the European Community, Oxford University Press, Oxford.

Pedler, R. and M. Van Schendelen (eds.) (1994), Lobbying the European Union: companies, trade associations and issue groups, Dartmouth, Aldershot.

Platform of European Social NGOs (May 1998), Implementing NGO Consultations: remarks on the communication of the European Commission (COM (97), 241). Brussels.

Platform of European Social NGOs (October 1998), Platform Report. Brussels.

Platform of European Social NGOs (June 1999), The Funding of European Social NGOs, Brussels.

Platform of European Social NGOs (October 1999), Political Recommendations on Civil Dialogue with NGOs at European Union Level, Brussels.

Platform of European Social NGOs (November 1999), Civil Dialogue: the role of social NGOs in the European Union, Brussels.

Rosamond, B. (2000), Theories of European Integration, Macmillan, London.

Springer, B. (1994), The European Union and Its Citizens, Greenwood Press, New York.

Sykes, R. and P. Alcock (eds.) (1998), Developments in European Social Policy: convergence and diversity, The Policy Press, Bristol.

Taylor, A. (2000), 'Is civil society heard in Brussels?' European Essay No.4, The Federal Trust, London. 